\title{
Influence of premolar extractions on the facial profile evaluated by the Holdaway analysis
}

\author{
Influência de exodontias de pré-molares no perfil facial \\ avaliada pela análise de Holdaway
}

\begin{abstract}
Purpose: This retrospective study aimed at assessing patients treated with extraction of premolars through cephalometry in lateral teleradiography, comparing the effect of different tooth extraction protocols on the facial profile.

Methods: For this study, 87 patients ( 31 boys and 56 girls) were selected from the private practices of three dentists certified by the Brazilian Board of Orthodontics and Facial Orthopedics. These patients were treated with fixed edgewise appliance and divided into three groups, according to the sequence in which premolars were extracted "Group 40" comprised 22 patients treated with extractions of the first two superior premolars, adopted as the control group; "Group 44" comprised 43 patients treated with extractions of the four first premolars; and "Group 45" comprised 22 patients treated with extractions of first superior premolars and second inferior premolars. The Holdaway analysis was used to quantify and compare the group profiles before and after treatment.

Results: Student's t-tests showed a profile improvement in all groups. When groups were compared, ANOVA showed that only the Inferior sulcus to the $\mathrm{H}$ line showed differences in incremental changes resulting from the treatment. Group 44 showed a significantly higher difference than Group 40.

Conclusion: We conclude that the protocols produce similar facial appearances.
\end{abstract}

Key words: Dental extraction; premolar tooth; corrective orthodontics

\section{Resumo}

Objetivo: Este trabalho retrospectivo tem como proposta avaliar pacientes tratados com exodontias de pré-molares através de cefalometria em telerradiografia de perfil, comparando o efeito de diferentes protocolos de exodontias no perfil.

Metodologia: Oitenta e sete pacientes ( 31 meninos e 56 meninas) foram selecionados da clínica particular de três ortodontistas diplomados pelo Board Brasileiro de Ortodontia e Ortopedia Facial. Estes pacientes foram tratados com aparelho fixo Edgewise foram divididos em três grupos, compreendendo a sequência de exodontia de pré-molares empregada Grupo 40 compreendendo 22 pacientes tratados com exodontia de primeiros pré-molares superiores, Grupo 44 compreendendo 43 pacientes tratados com exodontia de quatro primeiros prémolares e Grupo 45 compreendendo 22 pacientes tratados com exodontia de primeiros prémolares superiores e segundos inferiores. A Análise de Holdaway foi utilizada para quantificar e comparar os perfis antes e após o tratamento dos grupos.

Resultados: O teste t-Student mostrou melhora no perfil em todos os grupos. Quando comparados entre si, ANOVA revelou que apenas a medida sulco lábio inferior em relação à linha $\mathrm{H}$ apresentou diferenças nas mudanças incrementais proporcionadas pelo tratamento, em que o grupo 44 apresentou uma diferença significativamente superior ao grupo 40 .

Conclusão: A partir dos resultados concluiu-se que os protocolos produzem aparências faciais semelhantes.

Palavras chaves: Extração dentária; dente pré-molar; ortodontia corretiva

\section{Susiane Allgayer a \\ Eduardo M. Santayana de Lima a Maurício Barbieri Mezomo b}

a Department of Orthodontics, Pontifícia Universidade Católica do Rio Grande do Sul, Porto Alegre, RS, Brazil

b Department of Orthodontics, UNIFRA, Santa Maria, RS, Brazil

\author{
Correspondence: \\ Susiane Allgayer \\ Pontifícia Universidade Católica do Rio Grande do Sul \\ Faculdade de Odontologia \\ Av. Ipiranga, 6681 - Prédio 06 - Sala 209 \\ Porto Alegre, RS - Brazil \\ 90619-900 \\ E-mail: susianeallgayer@gmail.com \\ Received: September 18, 2010 \\ Accepted: November 14, 2010 \\ Conflict of Interest Statement: The authors state \\ that there are no financial and personal conflicts of \\ interest that could have inappropriately influenced \\ their work. \\ Copyright: (C) 2011 Allgayer et al.; licensee \\ EDIPUCRS. This is an Open Access article distributed \\ under the terms of the Creative Commons Attribution- \\ Noncommercial-No Derivative Works 3.0 Unported \\ License.
}




\section{Introduction}

In recent years, there has been a noticeable increase in awareness and interest in facial aesthetics (1). The aesthetic benefits are among the main goals of orthodontic treatment, and clinicians are often asked about possible changes in the profile caused by certain treatment plan. The fact that dental extractions may cause a "flat face" (2) due to excessive retraction has discouraged this type of treatment protocol. However, extractions can benefit the profile when properly indicated (3). To protect the lip and the facial profile, Nance $(4,5)$ suggested the extraction of first superior premolars and second inferior premolars. The choice among the possible sequences of premolar extraction is based on clinical observations, with little scientific support (6).

The study of beauty and harmony in the facial profile has long been a priority in orthodontic practice (7). Treatment mechanics have become more effective, thereby increasing the importance of soft tissues in both the diagnosis and treatment results. Holdaway (8) and Burstone $(9,10)$ are among the many scholars who have emphasized the importance of soft tissues in diagnosis (7).

There is general agreement that orthodontic treatment can influence the soft tissue profile of the face, but there is still disagreement on the magnitude of soft tissue response regarding changes in tooth position and alveolar process. Based on these points and using the Holdaway soft tissue analysis, this study was designed to evaluate the effects of three prescribed premolar extraction sequences ( $\mathrm{G} 40, \mathrm{G} 44$ and $\mathrm{G} 45$ ) on the lateral facial profile.

\section{Methods}

The sample was retrospectively selected from the private practice of three orthodontists certified by the Brazilian Board of Orthodontics and Dentofacial Orthopedics. The initial (T1) and final (T2) profile teleradiographies of 87 patients treated orthodontically with fixed edgewise appliances were divided into the following three groups according to the sequence in which premolars were extracted: 22 patients treated with extractions of the first two superior premolars, adopted as the control group (Group 40); 43 patients treated with extractions of the four first premolars (Group 44) and 22 patients treated with extractions of first superior premolars and second inferior premolars (Group 45). The mean age was 15 years (ranging from 11 to 18 years of age), with 31 boys and 56 girls. Treatment time was 3 years (ranging from 2 to 5 years).

The orthodontic mechanics included fixed edgewise appliance with 0.022 " $\times 0.028$ " slot brackets and a typical sequence of arches, starting with 0.0175 " coaxial or 0.016 " nickel titanium, followed by $0.016 ", 0.018$ ", 0.020 ", and $0.019 " \times 0.025$ " steel arches ( $3 \mathrm{M}$ Unitek, Monrovia, CA). Next, sliding mechanics were used to close residual spaces.

The sample was selected based solely on the premolar extraction sequence, regardless of other dentoalveolar or skeletal characteristics. Additional inclusion criteria for this study were (1) all patients had their premolars extracted as part of their consented treatment plan; (2) all patients were Caucasian, without congenitally missing teeth or previous extractions; (3) all permanent teeth were present up to the second molars; (4) good quality of the pre- and posttreatment radiographs, taken with the lips relaxed, teeth in occlusion, and using the same cephalosta (5) no prior use of functional appliances or orthognathic surgery between the two radiographs; (6) fully closed gaps at the end of treatment; (7) gaps closed with 0.019 " $\times 0.025$ " steel arches; and (8) where possible, maintenance of the intercanine and intermolar distances.

The radiographs were taken in centric occlusion, according Broadbent's technique (12), with lips at rest, as defined by Burstone (10). The cephalometric tracings in each profile teleradiography were performed manually by the same investigator and the cephalometric points were digitized into the Dentofacial Planner software (2.0 Toronto, Ontario, Canada) to obtain the cephalometric measurements. Nine linear and two angular measurements demarcated as per Holdaway (8) and defined by Basciftci et al. (13) were analyzed (Fig. 1 and 2).

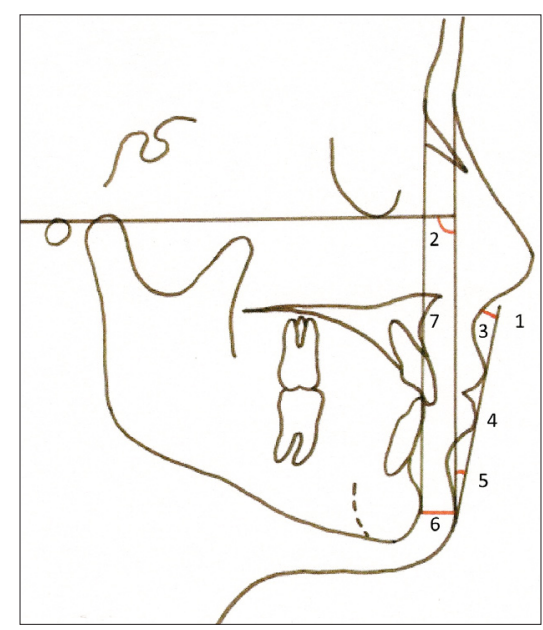

Fig. 1. Cephalometric measurements: 1, $\mathrm{H}$ line; 2 , Soft tissue facial angle; 3, Measurement of soft tissue subnasale to $\mathrm{H}$ line; 4 , Lower lip to $\mathrm{H}$ line; 5, $\mathrm{H}$ angle; 6, Soft-tissue chin thickness; 7, Skeletal profile convexity.

Fig. 2. Cephalometric measurements: 8, Nose prominence; 9, Upper lip sulcus depth; 10, Inferior sulcus to the $\mathrm{H}$ line (lower lip sulcus depth); 11, Basic upper lip thickness; 12, Upper strain measurement.

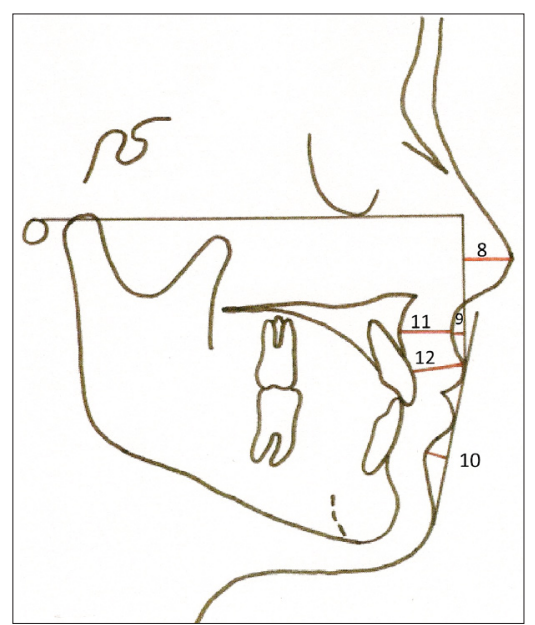


- H line: tangent drawn from the tip of the chin to the upper lip;

- Soft tissue facial angle: the downward and inner angle formed at a point where the sella-nasion line crosses the soft tissue and a line combining the suprapogonion with the Frankfort horizontal plane;

- Measurement of soft tissue subnasale to H line: measurement from subnasale to the $\mathrm{H}$ line;

- Lower lip to $\mathrm{H}$ line: the measurement of the lower lip to the $\mathrm{H}$ line;

- $\mathrm{H}$ angle: the angle formed between the soft-tissue facial plane line and the $\mathrm{H}$ line;

- Soft-tissue chin thickness: the distance between the hard and soft-tissue facial planes at the level of suprapogonion;

- Skeletal profile convexity: the dimension between point A and facial line;

- Nose prominence: the dimension between the tip of the nose and a perpendicular line drawn to the Frankfort plane from the vermillion;

- Upper lip sulcus depth: the measurement between the upper lip sulcus and a perpendicular line drawn from the vermillion to the Frankfort plane;

- Inferior sulcus to the H line (lower lip sulcus depth): the measurement at the point of greatest convexity between the vermillion border of the lower lip and the $\mathrm{H}$ line;

- Basic upper lip thickness: the dimension measured approximately three mm below point $\mathrm{A}$ and the drape of the upper lip; and

- Upper lip strain measurement: the dimension between the vermillion point and the labial surface of the upper incisor.

\section{Error Assessment}

To assess the intra-examiner error, 30 lateral teleradiographies were randomly selected and traced again after a 3-week interval. To evaluate the agreement between the first and second measurements, we used Student's t test for paired samples at a 5\% significance level. None of the measurements presented significant differences, which confirmed the calibration of the examiner.

Comparative analysis among the groups in the sample

The changes from T1 to T2 were evaluated to determine statistically significant variations that occurred separately in each of the groups.

\section{Statistical Analysis}

Normal distribuition of the data was confirmed by the nonparametric Kolmogorov-Smirnov test, and parametric tests were therefore applied. Initial (T1) and follow-up (T2) measurements were compared by Student's t-test for paired samples. Comparison among groups, was performed with analysis of variance (ANOVA). The results were considered statistically significant at a level of 5\%. All statistical tests used to process and analyze the data were performed with SPSS software package (SPSS 10.0., Chicago, III).

\section{Results}

Intragroup analysis (Table 1)

In all groups there was an increase in Nose prominence $(P<0.05)$ and a decrease in Upper lip sulcus depth, subnasale to $\mathrm{H}$ line, Skeletal profile convexity, $\mathrm{H}$ angle, and $(P<0.05)$. Upper lip base thickness, Upper lip strain increased in groups 40 and $44(P<0.05)$. Inferior sulcus to the $\mathrm{H}$ line increased in groups 44 and $45(P<0.05)$. Lower lip to $\mathrm{H}$ line decreased in groups 44 and $45(P<0.05)$.

Intergroup analysis (Table 2)

The results of the ANOVA test indicate that only the measurement Inferior sulcus to the $\mathrm{H}$ line showed a significant difference among the study groups $(P<0.05)$. There was a greater increase in Inferior sulcus to $H$ line for Group 44.

Table 1. Results of the comparison between the times T2 and T1.

\begin{tabular}{|c|c|c|c|c|c|c|c|}
\hline \multirow[t]{2}{*}{ Measurement } & \multicolumn{2}{|c|}{$\begin{array}{l}\text { Pretreatment } \\
\text { (T1) }\end{array}$} & \multicolumn{2}{|c|}{$\begin{array}{l}\text { Posttreatment } \\
\text { (T2) }\end{array}$} & \multicolumn{2}{|c|}{$\begin{array}{c}\text { Difference } \\
\text { (T2 -T1) }\end{array}$} & \multirow[t]{2}{*}{$P$} \\
\hline & Mean & SD & Mean & DP & Mean & SD & \\
\hline \multicolumn{8}{|l|}{ Group $40(n=22)$} \\
\hline Soft-tissue facial angle & 89.11 & 3.80 & 89.60 & 4.41 & 0.50 & 1.86 & 0.225 \\
\hline Nose prominence & 11.49 & 3.33 & 15.51 & 3.87 & 4.02 & 2.54 & $0.000^{*}$ \\
\hline Upper lip sulcus depth & 3.30 & 1.09 & 2.74 & 1.07 & -0.55 & 0.96 & $0.013^{*}$ \\
\hline Soft tissue subnasale to $\mathrm{H}$ line & 7.47 & 3.39 & 5.08 & 2.83 & -2.39 & 2.13 & $0.000^{*}$ \\
\hline Skeletal profile convexity & 5.08 & 2.72 & 3.36 & 3.06 & -1.72 & 1.78 & $0.000^{*}$ \\
\hline Basic upper lip thickness & 15.97 & 1.56 & 17.41 & 1.83 & 1.44 & 1.44 & $0.000^{*}$ \\
\hline Upper lip strain & 13.94 & 1.48 & 15.47 & 2.27 & 1.54 & 1.99 & $0.002^{*}$ \\
\hline $\mathrm{H}$ angle & 19.20 & 3.46 & 16.29 & 3.68 & -2.92 & 2.83 & $0.000^{*}$ \\
\hline Lower lip to $\mathrm{H}$ line & 0.50 & 2.16 & 0.08 & 1.60 & -0.42 & 1.39 & 0.169 \\
\hline Inferior sulcus to the $\mathrm{H}$ line & 5.87 & 1.69 & 5.85 & 1.64 & -0.02 & 0.97 & 0.931 \\
\hline Soft-tissue chin thickness & 11.70 & 1.96 & 11.96 & 1.93 & 0.25 & 1.06 & 0.272 \\
\hline
\end{tabular}


Table 1 (cont.)

\begin{tabular}{|c|c|c|c|c|c|c|c|}
\hline \multirow{2}{*}{ Measurement } & \multicolumn{2}{|c|}{ Pretreatment (T1) } & \multicolumn{2}{|c|}{ Posttreatment (T2) } & \multicolumn{2}{|c|}{ Difference (T2-T1) } & \multirow{2}{*}{$P$} \\
\hline & Mean & SD & Mean & DP & Mean & SD & \\
\hline \multicolumn{8}{|l|}{ Group $44(n=43)$} \\
\hline Soft-tissue facial angle & 89.03 & 3.49 & 88.73 & 3.70 & -0.30 & 2.32 & 0.409 \\
\hline Nose prominence & 11.10 & 3.12 & 15.73 & 3.42 & 4.62 & 2.53 & $0.000^{*}$ \\
\hline Upper lip sulcus depth & 3.30 & 1.58 & 2.56 & 1.37 & -0.73 & 1.24 & $0.000^{*}$ \\
\hline Soft tissue subnasale to $\mathrm{H}$ line & 7.07 & 2.75 & 4.39 & 2.72 & -2.68 & 2.20 & $0.000^{*}$ \\
\hline Skeletal profile convexity & 3.44 & 2.52 & 1.94 & 2.65 & -1.50 & 2.07 & $0.000^{*}$ \\
\hline Basic upper lip thickness & 15.24 & 1.72 & 16.03 & 2.04 & 0.80 & 2.00 & $0.012^{*}$ \\
\hline Upper lip strain & 12.72 & 1.70 & 14.07 & 2.21 & 1.35 & 1.87 & $0.000^{*}$ \\
\hline $\mathrm{H}$ angle & 16.91 & 3.91 & 13.66 & 3.42 & -3.26 & 3.15 & $0.000^{*}$ \\
\hline Lower lip to $\mathrm{H}$ line & 2.55 & 2.00 & 1.22 & 1.68 & -1.33 & 1.70 & $0.000^{*}$ \\
\hline Inferior sulcus to the $\mathrm{H}$ line & 3.74 & 1.75 & 4.97 & 1.89 & 1.23 & 1.25 & $0.000 *$ \\
\hline Soft-tissue chin thickness & 11.57 & 2.43 & 11.61 & 2.49 & 0.04 & 1.76 & 0.877 \\
\hline \multicolumn{8}{|l|}{ Group $45(n=22)$} \\
\hline Soft-tissue facial angle & 90.59 & 3.29 & 90.98 & 3.78 & 0.39 & 2.96 & 0.548 \\
\hline Nose prominence & 12.05 & 3.63 & 15.10 & 4.26 & 3.05 & 2.41 & $0.000^{*}$ \\
\hline Upper lip sulcus depth & 3.34 & 1.34 & 2.66 & 1.64 & -0.68 & 1.01 & $0.005^{*}$ \\
\hline Soft tissue subnasale to $\mathrm{H}$ line & 6.20 & 1.83 & 3.78 & 2.32 & -2.42 & 1.89 & $0.000^{*}$ \\
\hline Skeletal profile convexity & 3.07 & 2.30 & 1.48 & 3.50 & -1.59 & 1.74 & $0.000^{*}$ \\
\hline Basic upper lip thickness & 14.98 & 1.45 & 15.43 & 1.84 & 0.45 & 1.36 & 0.136 \\
\hline Upper lip strain & 12.58 & 1.91 & 13.16 & 2.68 & 0.59 & 1.85 & 0.152 \\
\hline $\mathrm{H}$ angle & 15.88 & 3.60 & 13.24 & 4.29 & -2.64 & 2.51 & $0.000^{*}$ \\
\hline Lower lip to $\mathrm{H}$ line & 1.41 & 1.62 & 0.47 & 1.24 & -0.94 & 1.67 & $0.016^{*}$ \\
\hline Inferior sulcus to the $\mathrm{H}$ line & 4.23 & 1.63 & 4.85 & 1.53 & 0.62 & 1.25 & $0.030^{*}$ \\
\hline Soft-tissue chin thickness & 11.74 & 2.09 & 11.27 & 2.33 & -0.47 & 1.17 & 0.071 \\
\hline
\end{tabular}

* Significant difference, $P<0.05$.

Table 2. Comparison of the T2-T1 differences among the study groups (incremental changes between groups).

\begin{tabular}{|c|c|c|c|c|c|}
\hline Measurement & Group & $\mathrm{n}$ & Mean & SD & $P$ \\
\hline \multirow[t]{3}{*}{ Soft-tissue facial angle } & Group 40 & 22 & 0.50 & 1.86 & 0.360 \\
\hline & Group 44 & 43 & -0.30 & 2.32 & \\
\hline & Group 45 & 22 & 0.39 & 2.96 & \\
\hline \multirow[t]{3}{*}{ Nose prominence } & Group 40 & 22 & 4.02 & 2.54 & 0.063 \\
\hline & Group 44 & 43 & 4.62 & 2.53 & \\
\hline & Group 45 & 22 & 3.05 & 2.41 & \\
\hline \multirow[t]{3}{*}{ Upper lip sulcus depth } & Group 40 & 22 & -0.55 & 0.96 & 0.828 \\
\hline & Group 44 & 43 & -0.73 & 1.24 & \\
\hline & Group 45 & 22 & -0.68 & 1.01 & \\
\hline \multirow[t]{3}{*}{ Soft tissue subnasale to $\mathrm{H}$ line } & Group 40 & 22 & -2.39 & 2.13 & 0.828 \\
\hline & Group 44 & 43 & -2.68 & 2.20 & \\
\hline & Group 45 & 22 & -2.42 & 1.89 & \\
\hline \multirow[t]{3}{*}{ Skeletal profile convexity } & Group 40 & 22 & -1.72 & 1.78 & 0.905 \\
\hline & Group 44 & 43 & -1.50 & 2.07 & \\
\hline & Group 45 & 22 & -1.59 & 1.74 & \\
\hline \multirow[t]{3}{*}{ Basic upper lip thickness } & Group 40 & 22 & 1.44 & 1.44 & 0.157 \\
\hline & Group 44 & 43 & 0.80 & 2.00 & \\
\hline & Group 45 & 22 & 0.45 & 1.36 & \\
\hline \multirow[t]{3}{*}{ Upper lip strain } & Group 40 & 22 & 1.54 & 1.99 & 0.200 \\
\hline & Group 44 & 43 & 1.35 & 1.87 & \\
\hline & Group 45 & 22 & 0.59 & 1.85 & \\
\hline \multirow[t]{3}{*}{$\mathrm{H}$ angle } & Group 40 & 22 & -2.92 & 2.83 & 0.714 \\
\hline & Group 44 & 43 & -3.26 & 3.15 & \\
\hline & Group 45 & 22 & -2.64 & 2.51 & \\
\hline \multirow[t]{3}{*}{ Lower lip to $\mathrm{H}$ line } & Group 40 & 22 & -0.42 & 1.39 & 0.107 \\
\hline & Group 44 & 43 & -1.33 & 1.70 & \\
\hline & Group 45 & 22 & -0.94 & 1.67 & \\
\hline \multirow[t]{3}{*}{ Inferior sulcus to the $\mathrm{H}$ line } & Group 40 & 22 & $-0.02^{A}$ & 0.97 & $0.001 *$ \\
\hline & Group 44 & 43 & $1.23^{\mathrm{B}}$ & 1.25 & \\
\hline & Group 45 & 22 & $0.62^{\mathrm{AB}}$ & 1.25 & \\
\hline \multirow[t]{3}{*}{ Soft-tissue chin thickness } & Group 40 & 22 & 0.25 & 1.06 & 0.238 \\
\hline & Group 44 & 43 & 0.04 & 1.76 & \\
\hline & Group 45 & 22 & -0.47 & 1.17 & \\
\hline
\end{tabular}

* Significant difference, $P<0.05$. Means values followed by the same letter do not differ. 
Table 3. Descriptive comparison of the T1 and T2 values of the sample using Holdaway Norms.

\begin{tabular}{|c|c|c|c|c|c|}
\hline \multirow[t]{2}{*}{ Measurement } & \multirow{2}{*}{$\begin{array}{l}\text { Norma } \\
\text { Holdaway }\end{array}$} & \multicolumn{2}{|c|}{$\begin{array}{l}\text { Pretreatment } \\
\text { (T1) }\end{array}$} & \multicolumn{2}{|c|}{$\begin{array}{c}\text { Posttreatment } \\
\text { (T2) }\end{array}$} \\
\hline & & Mean & SD & Mean & SD \\
\hline \multicolumn{6}{|l|}{ Grupo $40(n=22)$} \\
\hline Soft-tissue facial angle & $91 \pm 7$ & 89.11 & 3.80 & 89.60 & 4.41 \\
\hline Nose prominence & 14 a 24 & 11.49 & 3.33 & 15.51 & 3.87 \\
\hline Upper lip sulcus depth & 1 a 4 & 3.30 & 1.09 & 2.74 & 1.07 \\
\hline Soft tissue subnasale to $\mathrm{H}$ line & $5 \pm 2$ & 7.47 & 3.39 & 5.08 & 2.83 \\
\hline Skeletal profile convexity & 0 & 5.08 & 2.72 & 3.36 & 3.06 \\
\hline Basic upper lip thickness & 15 & 15.97 & 1.56 & 17.41 & 1.83 \\
\hline Upper lip strain & $13,5 \pm 0,5$ & 13.94 & 1.48 & 15.47 & 2.27 \\
\hline $\mathrm{H}$ angle & 10 [7 a 15] & 19.20 & 3.46 & 16.29 & 3.68 \\
\hline Lower lip to $\mathrm{H}$ line & $0[-1 a+2]$ & 0.50 & 2.16 & 0.08 & 1.60 \\
\hline Inferior sulcus to the $\mathrm{H}$ line & 5 & 5.87 & 1.69 & 5.85 & 1.64 \\
\hline Soft-tissue chin thickness & $11 \pm 1$ & 11.70 & 1.96 & 11.96 & 1.93 \\
\hline \multicolumn{6}{|l|}{ Grupo $44(n=43)$} \\
\hline Soft-tissue facial angle & $91 \pm 7$ & 89.03 & 3.49 & 88.73 & 3.70 \\
\hline Nose prominence & 14 a 24 & 11.10 & 3.12 & 15.73 & 3.42 \\
\hline Upper lip sulcus depth & 1 a 4 & 3.30 & 1.58 & 2.56 & 1.37 \\
\hline Soft tissue subnasale to $\mathrm{H}$ line & $5 \pm 2$ & 7.07 & 2.75 & 4.39 & 2.72 \\
\hline Skeletal profile convexity & 0 & 3.44 & 2.52 & 1.94 & 2.65 \\
\hline Basic upper lip thickness & 15 & 15.24 & 1.72 & 16.03 & 2.04 \\
\hline Upper lip strain & $13,5 \pm 0,5$ & 12.72 & 1.70 & 14.07 & 2.21 \\
\hline $\mathrm{H}$ angle & 10 [7 a 15] & 16.91 & 3.91 & 13.66 & 3.42 \\
\hline Lower lip to $\mathrm{H}$ line & $0[-1 a+2]$ & 2.55 & 2.00 & 1.22 & 1.68 \\
\hline Inferior sulcus to the $\mathrm{H}$ line & 5 & 3.74 & 1.75 & 4.97 & 1.89 \\
\hline Soft-tissue chin thickness & $11 \pm 1$ & 11.57 & 2.43 & 11.61 & 2.49 \\
\hline \multicolumn{6}{|l|}{ Grupo $45(n=22)$} \\
\hline Soft-tissue facial angle & $91 \pm 7$ & 90.59 & 3.29 & 90.98 & 3.78 \\
\hline Nose prominence & 14 a 24 & 12.05 & 3.63 & 15.10 & 4.26 \\
\hline Upper lip sulcus depth & 1 a 4 & 3.34 & 1.34 & 2.66 & 1.64 \\
\hline Soft tissue subnasale to $\mathrm{H}$ line & $5 \pm 2$ & 6.20 & 1.83 & 3.78 & 2.32 \\
\hline Skeletal profile convexity & 0 & 3.07 & 2.30 & 1.48 & 3.50 \\
\hline Basic upper lip thickness & 15 & 14.98 & 1.45 & 15.43 & 1.84 \\
\hline Upper lip strain & $13,5 \pm 0,5$ & 12.58 & 1.91 & 13.16 & 2.68 \\
\hline $\mathrm{H}$ angle & 10 [7 a 15] & 15.88 & 3.60 & 13.24 & 4.29 \\
\hline Lower lip to $\mathrm{H}$ line & $0[-1 a+2]$ & 1.41 & 1.62 & 0.47 & 1.24 \\
\hline Inferior sulcus to the $\mathrm{H}$ line & 5 & 4.23 & 1.63 & 4.85 & 1.53 \\
\hline Soft-tissue chin thickness & $11 \pm 1$ & 11.74 & 2.09 & 11.27 & 2.33 \\
\hline
\end{tabular}

\section{Discussion}

The growth process creates, by itself, facial changes. Therefore, the goal of many studies has been to establish a prognosis of the changes that will occur in the faces of patients under the cumulative effect of growth, development, and orthodontic treatment (14). This work was performed with patients in an active growth age group, which was part of the study inclusion criteria. Additionally, the study sample was compatible in terms of age at the beginning and end of treatment and in the duration of treatment $(3,15)$. According to Talass (16), growth is associated with minimal changes in the soft tissues when the treatment period does not exceed 36 months.

\section{Intragroup analysis (Tables 1 and 3)}

The nose prominence increased significantly in all three groups. This increase was favorable because the values were all sub-standard at the beginning of treatment. Hoffelder and Lima (17) highlighted the aesthetic implications of the size and shape of the nose, which changes up to 18 years of age. Subtenly (18) recommends that treatment during adolescence should be completed with more prominent lips due to the large expected increase in the nose and chin. Castro (5) comments that the nose "is individual", i.e., it is difficult to predict its growth because it varies significantly during the treatment period and from one patient to another. A number of studies have suggested evaluating the posture of the lips and the aesthetics $(19,20)$ but most are influenced by nose growth. Holdaway (8) removed nasal influence from the labial posture assessment (7).

The Holdaway's soft tissue analysis is the only one that determined values for the upper lip sulcus depth $(2,8)$. There is a need to consider the upper lip curve during the treatment plan to reduce the potential for undesirable expressions in this region, apparently as a result of an excessive retraction of the upper and lower teeth during treatment. 


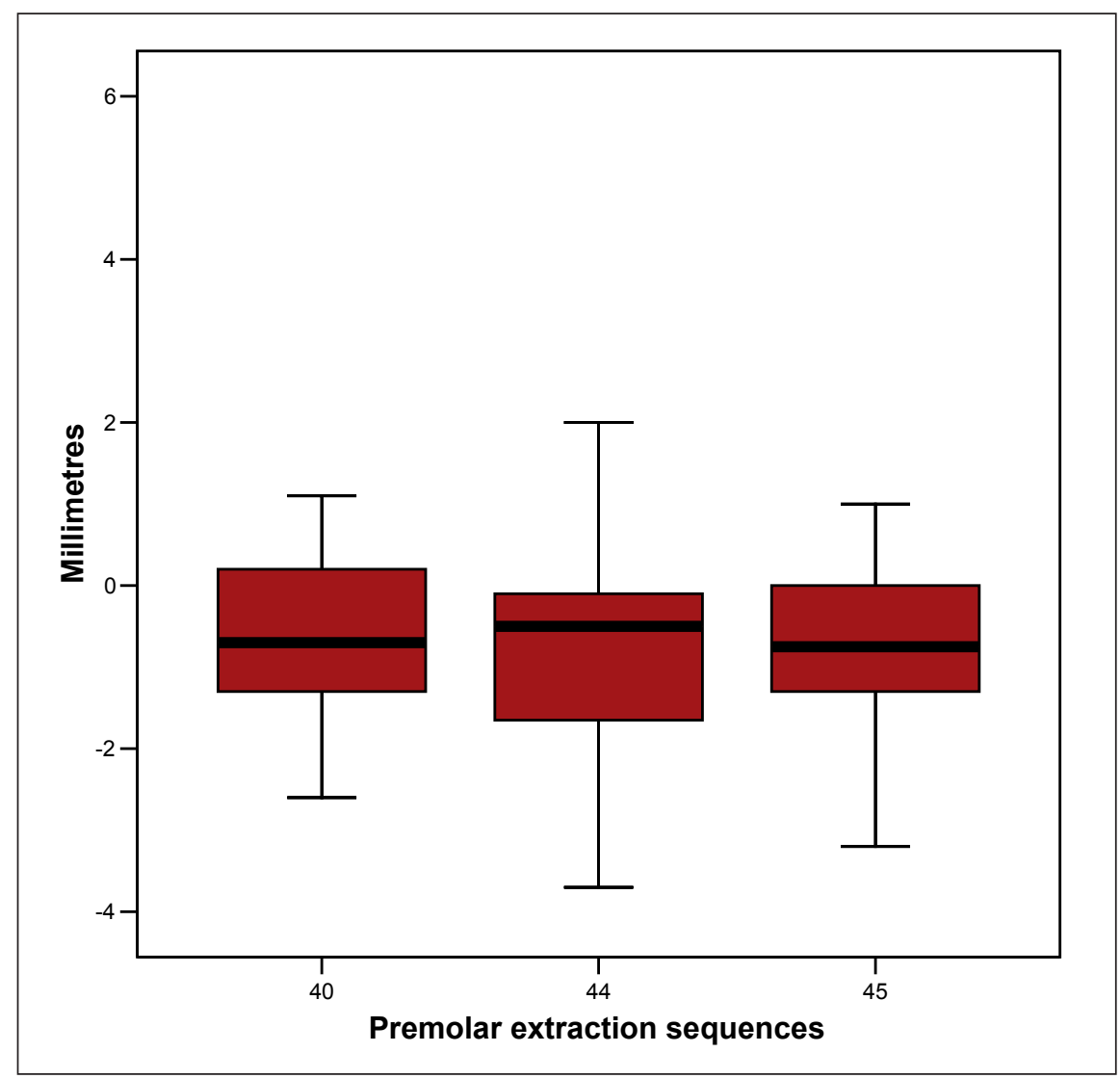

Fig. 3. Changes in the upper lip sulcus depth.

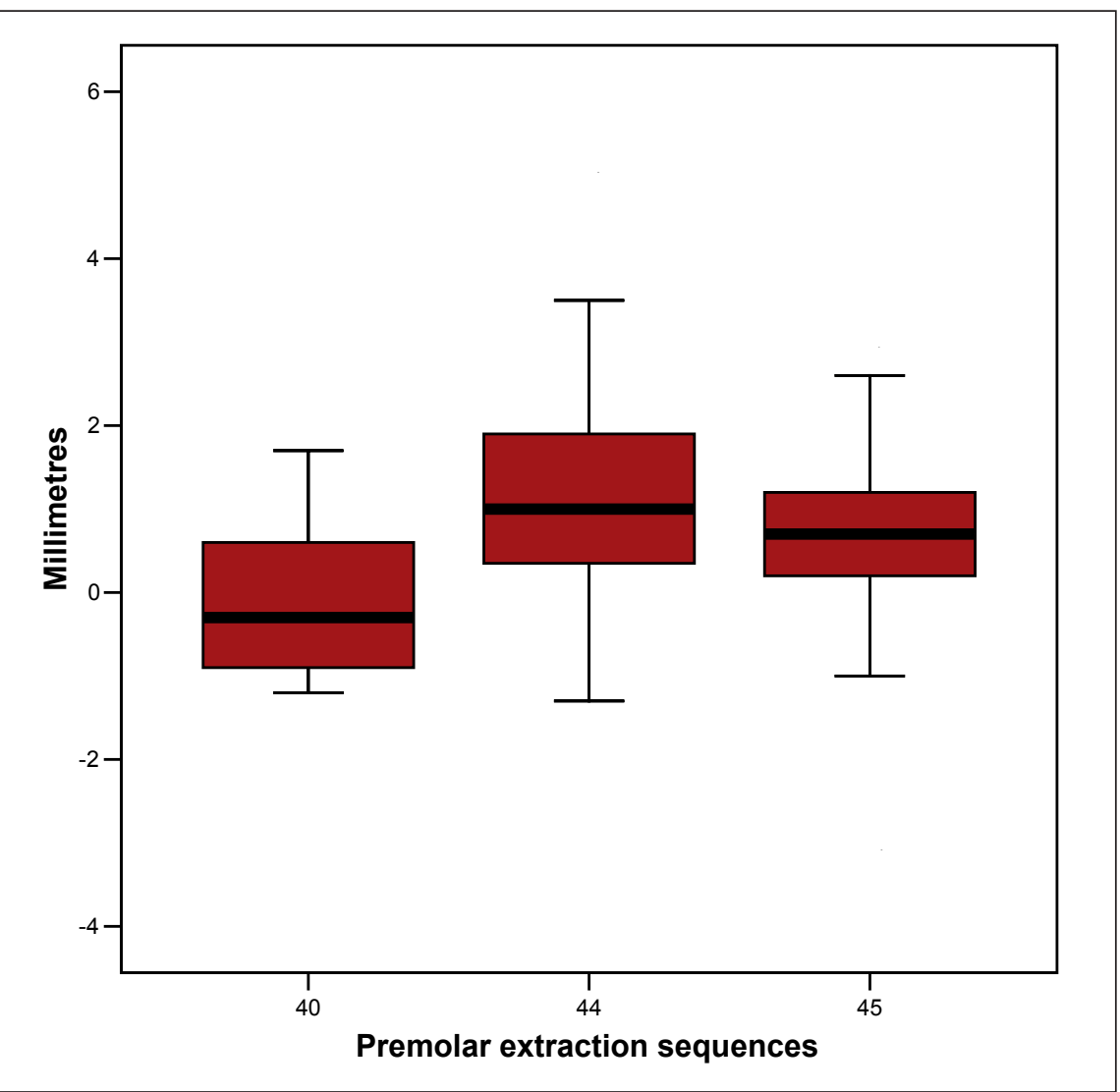

Fig. 4. Changes in the inferior sulcus to the $\mathrm{H}$ line. 
The upper lip sulcus depth and the extent of soft tissue subnasale to $\mathrm{H}$ were, on average, significantly reduced after treatment in all groups. Wholley and Woods (6) and Moseling and Woods (11) found large individual variation, with both increases and decreases in the two measures. In this study, only Group 40 showed both increases and decreases in the upper lip sulcus depth (Fig. 3). Holdaway (8) indicated that skeletal profile convexity is not really a measure of soft tissue; instead, convexity is directly related to the harmonious position of the lips, being a reference of the dental relationship necessary to create balanced facial features. In this study, a significant reduction during the treatment period established favorable changes in the aesthetics of these patients in all groups, approximating to the ideal values.

Burstone (10) stated that one of the goals of orthodontic treatment is to minimize the stretching of the lips upon sealing in patients with dentofacial disharmonies. In the present study, the basic upper lip and upper lip strain increased in the three groups. The increase was statistically significant in Groups 40 and 44 . When comparing Groups 44 and 45, there was a significant increase only in Group 44, probably where the maximum anchorage is required for greater retraction of the incisors. Other factors are associated with lip response in addition to the kind of extraction that the patient has undergone: the complex anatomy of the lip, which often has an intrinsic response property $(7,14,15,21)$, and tension at the time of radiography $(6,7,16)$. The lip tension varies among individuals and among time periods with the same person.

The $\mathrm{H}$ angle measures the prominence of the upper lip in relation to the overall soft-tissue profile. This measure was significantly reduced in all groups during the orthodontic treatment and approximated to the norm without matching it. This is in agreement with Cappeli (22), who reported similar findings, suggesting that the differences could be attributed to variability among the Caucasians evaluated in that study.

According to Burstone (9), support for the inferior incisors and extrusion of superior incisors project the lower lip the same way a flaccid lower lip or an abnormal lip morphology affect the lower lip inclination. The lower lip was significantly reduced from T1 to T2 in Groups 44 and 45. Group 44 had more retraction of the lower lip (1.33) than Group 45 (0.94), which is consistent with some previous studies $(4,23)$. In the lower arch, the extraction of second premolars is a strategy to camouflage Class II maxillary relationships. The mesial movement of inferior molars is stimulated, thereby closing the inferior gaps, correcting the molar Class II relationship. The degree of mesial movement of molars depends on the amount of space left after the alignment of lower incisors and canine retraction. Therefore, the extraction of first superior premolars and second inferior premolars are indicated in cases with an absence of severe crowding or excessive protrusion of the lower incisors (so that the extraction spaces are available for anteroposterior tooth movement and not for the correct alignment of the incisors). The molar moves more forward $(5,23-25)$ when the second premolar is extracted and less retraction of the lower lip is expected when this tooth is extracted $(4,23,24)$. However, the lower lip retraction was not statistically significant different between Groups 44 and 45 . Hershey (14) and Wisth (21) emphasize that individual variations make lip retraction impossible to predict.

According to Holdaway (8), the contour of the inferior sulcus to the $\mathrm{H}$ line should be in harmony with the shape of the upper lip groove. This measure is an indicator to produce a good handling of the axial position of the lower incisors. Groups 44 and 45 had an increase in the sulcus of 1.23 and 0.62 , respectively, with no statistical difference between them. This change approximated these values to the standard values. In Group 40, there were no changes (0.02). In contrast, Wholley and Woods (6) found a significant reduction of the sulcus in their group 45. Our lower lip groove observations also contrast with those of Wholley and Woods (6) and Moseling and Woods (11), who found large individual variation, with both increases and decreases in the measures. In the present study, only Group 40 showed both increases and decreases in the sulcus (Fig. 4). Holdaway (8) and Hershey (14) suggest that there is more variation in the lower lip area compared to the upper lip area; yet Moseling and Woods (11) found more correlation and more predictability in the inferior sulcus than the superior.

Intergroup analysis of incremental changes (Table 2)

In this study, the inferior sulcus to the $\mathrm{H}$ line was the only variable that showed a significant difference among groups. This suggested that, when extracting the first inferior premolars in Group 44, it was desirable a greater retraction of the lip than in Group 45, where second premolars were extracted and there was a greater mesial movement of the molars. Group 40 did not exhibit changes in the measurements of the inferior sulcus, which was expected as no extraction was performed in the lower arch. The measure was in accordance with the recommended $5 \mathrm{~mm}$, and changes were not desired (Table 3). As the changes caused by treatment to all other variables were similar between groups, it may be suggested that treatment protocols produce equivalent results in patients.

\section{Conclusions}

The facial profile results after treatment with various extraction protocols were similar using the Holdaway soft tissue analysis.

\section{Acknowledgments}

This work was done In partial fulfillment of the first author's requirements for the masters degree in orthodontics at the Pontifícia Universidade Católica do Rio Grande do Sul. 
1. Conley RS, Jernigan C. Soft tissue changes after upper premolar extraction in Class II camouflage therapy. Angle Orthod 2006;76:59-65.

2. James RD. A comparative study of facial profiles in extraction and nonextraction treatment. Am J Orthod Dentofacial Orthop 1998;1 14:265-76.

3. Janson G, Fuziy A, Freitas MR, Henriques JFC, Almeida RR. Soft-tissue treatment changes in Class II Division 1 malocclusion with and without extractions of maxillary premolars. Am J Orthod Dentofacial Orthop 2007;132:729.e1-729.e8.

4. Nance HN. The removal of second premolars in orthodontic treatment. Am J Orthod 1949;35:685-96.

5. Castro N. Second premolar extraction in clinical procedures. Am J Orthod 1974;65: 115-37.

6. Wholley CJ, Woods MG. The effects of commonly prescribed premolar extraction sequences on the curvature of the upper and lower lips. Angle Orthod 2003;73:386-95.

7. Basciftci FA, Uysal T, Buyukerkmen A, Demir A. The influence of extraction treatment on Holdaway soft-tissue measurements. Angle Orthod 2004;74:167-73.

8. Holdaway RA. A soft -tissue cephalometric analysis and its use in orthodontic treatment planning. Part I. Am J Orthod Dentofacial Orthop 1983;84:1-28.

9. Leagan $\mathrm{HL}$, Burstone CJ, Conn F. Soft tissue cephalometric analysis for orthognatic surgery. J Oral Surg 1980;38:744-51.

10. Burstone CJ. Lip posture and its significance in treatment planning. Am J Orthod 1967;53:262-84.

11. Moseling KP, Woods MG. Lip curve changes in females with premolar extraction or nonextraction treatment. Angle Orthod 2004;74:51-62.

12. Broadbent BH. A new x-ray technique and its application to orthodontia. Angle Orthod $1931 ; 1: 45-66$

13. Basciftci FA, Uysal T, Buyukerkmen A. Determination of Holdaway soft tissue norms in Anatolian Turkish adults. Am J Orthod Dentofacial Orthop 2003;123:395-400.

14. Hershey HG. Incisor tooth retraction and subsequent profile change in postadolescent female patients Am J Orthod 1972;61:45-54.

15. Oliver BM. The infuence of lip thickness and strain on upper lip response to incisor retraction. Am J Orthod 1982;82:141-9.

16. Talass MF, Tollaae L, Baker RC. Soft-tissue profile changes resulting from retraction of maxillary incisors. Am J Orthod Dentofacial Orthop 1987;91:385-94.

17. Hoffelder LB, Lima EMS, Lima FMS, Bolognese AM. Soft-tissue changes during facial growth in skeletal Class II individuals. Am J Orthod Dentofacial Orthop 2007;131:490-5.

18. Subtelny JD. The soft tissue profile, growth and treatment changes. Angle Orthod 1961;31:105-22.

19. Ricketts RM. Esthetics environment and the law of tip relation. Am J Orthod 1968;54: 272-89.

20. Steiner CC. Cephalometrics as a clinical tool. In: Kraus BS, Riedel R. Vistas in Orthodontics. Philadelphia:Lea\&Febiger; 1962.

21. Wisth PJ. Soft tissue response to upper incisor retraction in boys. Br J Orthod 1974;1: 199-204.

22. Capelli JJ, Tibana RHW. Alterações no perfil facial em indivíduos submetidos a tratamento ortodôntico com extrações de quatro pré-molares. Ortodontia Gaúcha 2002;6:35-45.

23. Logan LR. Second premolar extraction in class I and class II. Am J Orthod 1973;63: $115-47$.

24. Schwab DT. The borderline patient and tooth removal. Am J Orthod 1971; 59:126-45.

25. Lee JS, Kim JK, Park YC, Vanardall RL. Aplicações dos miniimpantes ortodônticos. São Paulo: Quintessence Editora; 2009. 